\title{
Protection conferred on mice by monoclonal antibodies directed against outer-membrane-protein antigens of Brucella
}

\author{
A. CloeckAeRT, I. JACQUeS*, N. BOSSERAY*, J. N. LIMET, R. BOWDEN*, G. DUBRAY*† \\ and M. PLOMMET*
}

Unit of Experimental Medicine, Catholic University of Louvain, 75 avenue Hippocrate, Brussels, Belgium and *Institut National de la Recherche Agronomique, Station de Pathologie de la Reproduction, 37380 Nouzilly, France

\begin{abstract}
Summary. Twenty-six monoclonal antibodies (MAbs) directed against seven brucella outermembrane proteins (OMPs) of 10, 16.5, 19, 25-27, 31-34, 36-38 and $89 \mathrm{Kda}$ were screened for passive protection of mice; three MAbs (directed against 16.5, 25-27 and 36-38 Kda) reduced significantly the initial colonisation of the spleen measured 7 days after challenge. Although significant, the reduction in numbers of Brucella organisms in the spleen was low compared with that conferred by MAbs against lipopolysaccharide of smooth specificity (SLPS). The three most protective MAbs belonged to two isotypes (IgG1 and IgG2a) and were specific for three different OMPs. No relationship between protection and binding of MAbs to the challenge $\mathrm{S}$ strain or its rough mutant was observed in the mouse model. The humoral protection depended mainly on antibodies directed against S-LPS, although some MAbs against OMPs had weak protective activity.
\end{abstract}

\section{Introduction}

Brucellae are facultative intracellular parasites that cause brucellosis in animals and man. Protective immunity has been most extensively studied in a mouse model in which protection was mediated by $T$ lymphocytes ${ }^{1,2}$ and polyclonal antibodies of which the different specificities were not identified. ${ }^{2-4} \mathrm{Op}$ sonisation of Brucella organisms, either in vitro before injection ${ }^{5}$ or in vivo during the post-challenge bacteraemic phase, ${ }^{2,6-10}$ confers on mice an immune protection that may represent a large part of the vaccinal immunity. ${ }^{2,4}$ Whereas immune sera raised against the lipopolysaccharide extracted from smoothcell colonies (S-LPS) and against the outer-membrane protein (OMP)-linked peptidoglycan (PG) fractions were very efficient in protection, ${ }^{2}$ these sera contained too many antibody specificities to identify precisely the antigens involved (J. N. Limet, M. Plommet and G. Dubray, unpublished observations). For this reason, we used an indirect approach involving passive transfer of monoclonal antibodies (MAbs) to identify the antigens that elicit antibody-mediated protective immunity. In common with others, we demonstrated that MAbs directed against the polysaccharide $\mathrm{O}$ chain of S-LPS can confer protection on mice. ${ }^{8,11,12}$

Received 20 June 1990; accepted 22 Aug. 1990.

† Correspondence should be sent to Dr G. Dubray.
Brucella S-LPS bears major $A$ and $M$ specificities determined with monospecific sera and defining biovars of Brucella spp. ${ }^{13}$ MAbs of A or M specificity are able to protect mice passively in relation to the $A$ or M S-LPS specificity of the challenge strain. ${ }^{14}$ Other antigens may also be involved; in-vitro studies have indicated that at least two different types of antibody may help macrophages to ingest and digest Brucella organisms. ${ }^{15}$ In addition to S-LPS, major OMPs of the PG fraction may be putative candidates for humoral protective antigens because highly protective polyclonal anti-PG immune sera contain antibodies against these proteins.

We have now examined 26 MAbs directed against seven protein components of the outer membrane for protective ability in the mouse model.

\section{Materials and methods}

\section{Bacterial strains}

Challenge strains. B. abortus strain 544 (S) and (R) variants were obtained from the Station de Pathologie de la Reproduction (Nouzilly, Tours). Purity and phase were checked by standard procedures. ${ }^{13}$

Whole bacterial $S$ and $R$ cells for binding studies. Cell cultures were grown at $37^{\circ} \mathrm{C}$ for $48 \mathrm{~h}$ on slopes of Trypticase Soy Agar (TSA); BioMérieux, Marcy- 
l'Etoile, France) supplemented with yeast extract (Difco) $0 \cdot 1 \% \mathrm{w} / \mathrm{v}$. The bacteria were killed by addition of $20 \mu \mathrm{l}$ of peracetic acid (Aldrich-Chimie, Strasbourg, France) $5 \% \mathrm{v} / \mathrm{v}$ to each $1-\mathrm{ml}$ volume of $10^{10} \mathrm{cells} / \mathrm{ml}$, followed by incubation overnight at room temperature. Before use, killing efficiency was checked by spreading 0.2-ml samples of each cell suspension, after three washes in sterile distilled water, on TSA.

Bacterial fractions. Cell walls, and insoluble cell-wall fraction (PG fraction) obtained after boiling cell walls in sodium dodecyl sulphate (SDS) $4 \%$ solution, were extracted as described previously. ${ }^{16}$ Briefly, cells were inactivated by heating at $65^{\circ} \mathrm{C}$ for $1 \mathrm{~h}$ and broken with glass beads in a Braun MSK Homogenizer or a DynoMill apparatus (W. A. Bachofen, Basel, Switzerland). Crude cell walls were recovered by centrifugation $\left(53000 \mathrm{~g}, 4^{\circ} \mathrm{C}, 1.5 \mathrm{~h}\right)$. Cell walls from $B$. melitensis strain $B 115(R)$ were obtained by treating crude cell walls with Triton X-100 $1 \%$ in $0.2 \mathrm{M} \mathrm{NaCl}, 0.01 \mathrm{M}$ $\mathrm{MgCl}_{2}$ for $30 \mathrm{~min}$ at $20^{\circ} \mathrm{C}$, then washing them six times in distilled water before lyophilisation. PG fraction from $B$. melitensis strain $\mathrm{H} 38(\mathrm{R})$ was obtained by treating crude cell walls with SDS $4 \%$ in the Laemmli sample buffer for electrophoresis. Insoluble fractions were recovered by centrifugation, washed six times in distilled water and then lyophilised.

Cell extracts of $B$. abortus strain B115 (R) were obtained by ultrasonication. Cells were inactivated by heating at $65^{\circ} \mathrm{C}$ for $1 \mathrm{~h}$, washed three times in $\mathrm{NaCl}$ $0.9 \%$ and exposed to ultrasonication for $15 \mathrm{~min}$ in $1 \mathrm{~mm}$ EDTA, $30 \mathrm{~mm}$ Tris, pH 8. The ultrasonicated cells were then centrifuged for $10 \mathrm{~min}$ at $4000 \mathrm{~g}$ and the supernate was recovered.

LPS fractions. S-LPS fraction of B. abortus strain B3 (S-LPS of $A>M$ specificity) was prepared by the phenol-water method. ${ }^{17}$

\section{Production of monoclonal antibodies (MAbs)}

BALB/c mice were immunised by three weekly intraperitoneal (i.p.) injections of $100 \mu \mathrm{g}$ of PG fraction or cell wall. After 3 months, mice were given i.p. booster doses of $1 \mathrm{mg}$ of PG fraction or cell wall. Other BALB/c mice were infected by i.p. injection of $10^{9}$ live cells of $B$. abortus strain 45/20 (R) or strain B3 (S). After 4 months, these mice were given i.p. booster doses of $10^{9}$ heat-killed cells of $B$. abortus strain $45 / 20$ (R), or strain 99 (S). Four days after the booster injection, spleen cells were harvested and fused with cells of the NSO non-secreting myeloma cell line in a ratio of 5:1. After fusion, cells were suspended in selective hypoxanthine-aminopterin-thymidine-containing medium and seeded in 96-well microtitration plates at a concentration of $5 \times 10^{4}$ splenocytes per well. Anti-brucella hybridomas were screened by ELISA and cloned by the limiting dilution technique. Ascitic fluids were prepared in BALB/c mice according to the method of Limet et al. ${ }^{11}$ The anti-S-LPS MAb of A specificity was the $C$ used previously ${ }^{11}$ and identified as B66/04F09 (IgG2a isotype).
$M A b$ isotypes were determined by direct latex agglutination immunoassay of the culture supernates. Latex particles were coated with rat monoclonal anti-mouse IgG1, IgG2a, IgG2b, IgG3, IgM and polyclonal anti-mouse $\operatorname{IgA}$ as described previously. ${ }^{18}$

\section{Antisera}

Rabbit anti-mouse immunoglobulin antiserum (RAM) was produced by repeated intradermal injections of $100 \mu \mathrm{g}$ of mouse IgG. Rabbits were given injections of mouse IgG and bled every 2 weeks during several months. The best bleedings were pooled.

Rabbit anti-brucella antiserum was produced by repeated intradermal injections of $10^{9}$ killed cells of B. abortus strain 45/20 (R) or strain 99 (S). The immunoglobulin fraction was obtained by $\left(\mathrm{NH}_{4}\right)_{2} \mathrm{SO}_{4}$ precipitation.

\section{$E L I S A$}

Ascitic fluids were assayed for antibody activity by solid phase ELISA against fresh live and peracetic acid-inactivated $R$ bacterial cells. The MAb-binding results were similar with live or killed cells and, for safety reasons, we subsequently used only peracetic acid-killed cells. For ELISA we used as diluent phosphate-buffered saline, $0.02 \mathrm{M}, \mathrm{pH} \mathrm{7.2,} \mathrm{(PBS)} \mathrm{con-}$ taining Tween 20 (T) $0.05 \%$ (PBS-T). ${ }^{15}$ Bacterial cells were immobilised on microtitration plates (Greiner labortechnic-Stuttgart) by capture with rabbit antibrucella immunoglobulins at a coating concentration of $10 \mu \mathrm{g} / \mathrm{ml}$. Hybridoma supernates were serially diluted (from 1 in 10 to 1 in 590490) in glycine buffer saline-EDTA-Tween $(0.17 \mathrm{M} \mathrm{NaCl}, 0.1 \mathrm{M}$ glycine, $6 \mathrm{mM} \mathrm{NaN}_{3}, 50 \mathrm{~mm}$ EDTA, Tween 80 0.1\%, pH 9.2). Binding to whole bacterial cells was detected with peroxidase-conjugated goat anti-mouse immunoglobulins (Jackson ImmunoResearch Laboratories, West Grove, PA, USA) diluted in PBS-T. Excess of reagents between the different incubations was removed by five washings with saline containing Tween $200.05 \%$. For substrate solution, $52 \mathrm{mM}$ ABTS (2,2'-azino-di-[3ethyl-benzthiazoline sulphonate]; Boehringer, Mannheim, Germany) was dissolved in water and autoclaved at $121^{\circ} \mathrm{C}$ for $15 \mathrm{~min}$. The working substrate solution was made by adding $1 \mathrm{ml}$ of ABTS stock solution to $50 \mathrm{ml}$ of $0.1 \mathrm{M}$ sodium citrate buffer, $\mathrm{pH}$ $4 \cdot 2$, and $1 \mathrm{ml}$ of $\mathrm{H}_{2} \mathrm{O}_{2}\left(125 \mu \mathrm{l}\right.$ of $\mathrm{H}_{2} \mathrm{O}_{2} 30 \%$ in $10 \mathrm{ml}$ of distilled water).

The ELISA titres were estimated as the highest dilutions that gave an increase in light absorbance at $414 \mathrm{~nm}\left(\mathrm{~A}_{414}\right)$ more than twice the mean of the corresponding blank values (without MAb but with conjugate and substrate).

\section{Protection of mice}

MAbs were screened for protection of mice as described previously, ${ }^{11,14}$ except that two groups of 
four mice were used for each MAb, at ascitic fluid dilutions of 1 in 5 and 1 in 50. MAbs were injected subcutaneously $(0.1 \mathrm{ml}) 1$ day before the standard intravenous challenge with $B$. abortus strain $544(2 \times$ $10^{5} \mathrm{cfu}$ ). The mice were killed 7 days after challenge; individual spleen counts were made and were expressed as mean $\log _{10}$ and SD cfu per group. Two successive experiments were performed, with 12 and 16 MAbs respectively. Each experiment included two control groups, one of which received saline (negative control), the other anti-S-LPS MAb of A specificity (B66/04F09, IgG2a) as positive control. The statistical significance was determined after variance analysis by one-side comparison of means with the negative control mean according to Dunnett's procedure. ${ }^{19}$

\section{Immunoblot examination of MAbs}

Protein antigens in sonicated cell extracts of $B$. melitensis strain B115 (R) were separated by SDSpolyacrylamide gel electrophoresis (SDS-PAGE), as originally described by Laemmli, ${ }^{22}$ in a 2001 vertical electrophoresis unit (LKB-Produkter AB, Bromma, Sweden). After electrophoresis, the proteins were transferred to nitrocellulose with a Transblot apparatus (Biolyon, Dardilly, France) operated at $12 \mathrm{~V}$ for $2 \mathrm{~h}$. Unoccupied sites on the nitrocellulose membranes were blocked by incubation for $30 \mathrm{~min}$ in Tris-buffered saline (TBS) with bovine serum albumin (BSA) $3 \%$ at room temperature with agitation.

The membranes were then incubated successively at room temperature overnight with hybridoma supernates diluted 1 in 2 in Tween (Tw) TBS BSA 1\%, for $1 \mathrm{~h}$ with RAM and finally for a further hour with peroxidase-conjugated protein $A$, each diluted 1 in 250 and 1 in 1000, respectively, in the same buffer. Protein A (Sigma) was conjugated with horseradish peroxidase (Sigma) by a modification of the method of Nakane and Kawaoï ${ }^{20}$ as described previously. ${ }^{21}$ The protein: enzyme ratio was $1: 2$. Washings between incubation periods were with Tw-TBS. After two final washings with Tw-TBS and two washings with TBS, the blots were developed by incubation at room temperature in a solution of 4-chloro-1-naphthol

Table I. Protective activity and binding of the anti-brucella OMP MAbs to R and S Brucella cells (experiment 1)

\begin{tabular}{|c|c|c|c|c|c|c|c|}
\hline \multirow{3}{*}{$\begin{array}{l}\text { OMPs }\left(\mathbf{M}_{\mathbf{r}}\right) \text { Immunogen } \\
\text { clone no. }\end{array}$} & \multirow{3}{*}{ Isotype } & \multirow{2}{*}{\multicolumn{2}{|c|}{$\begin{array}{c}\text { Mean (SD) } \log _{10} \text { Brucella cfu } \\
\text { after treatment* } \\
\text { with MAb at dilution }\end{array}$}} & \multicolumn{4}{|c|}{ Binding of MAb to B. abortus strain } \\
\hline & & & & \multicolumn{2}{|c|}{$544(\mathrm{R})$} & \multicolumn{2}{|c|}{$544(S)$} \\
\hline & & 5 & 50 & Titre† & $\begin{array}{c}\text { Max } \\
\text { absorbance } \ddagger\end{array}$ & Titre† & $\begin{array}{c}\text { Max } \\
\text { absorbance } f\end{array}$ \\
\hline \multicolumn{8}{|l|}{$\begin{array}{l}\text { 25-27 Kda } \\
\text { Live B. abortus B3 }\end{array}$} \\
\hline A18/13D02/F05 & IgG1 & $6.09(0.42)$ & $6 \cdot 14(0 \cdot 14)$ & 196830 & $1 \cdot 518$ & 2430 & 1.078 \\
\hline $\mathrm{Al9} / 12 \mathrm{~B} 10 / \mathrm{F} 04$ & IgG1 & $5 \cdot 03(0 \cdot 26) \S$ & $5 \cdot 72(0 \cdot 04)$ & 65610 & $1 \cdot 416$ & 90 & 0.492 \\
\hline \multicolumn{8}{|l|}{ PG fraction from H38 (R) } \\
\hline $\begin{array}{l}\text { A59/01E11/D11 } \\
\text { A59/05F01/C09 }\end{array}$ & $\begin{array}{l}\operatorname{IgG} 2 a \\
\text { IgG2a }\end{array}$ & $\begin{array}{l}6 \cdot 15(0 \cdot 29) \\
6 \cdot 34(0 \cdot 14)\end{array}$ & $\begin{array}{l}6 \cdot 52(0 \cdot 16) \\
5 \cdot 84(0 \cdot 57)\end{array}$ & $\begin{array}{r}270 \\
65610\end{array}$ & $\begin{array}{l}1 \cdot 009 \\
1 \cdot 551\end{array}$ & $\begin{array}{r}30 \\
2430\end{array}$ & $\begin{array}{l}0 \cdot 626 \\
1 \cdot 231\end{array}$ \\
\hline \multicolumn{8}{|l|}{$\begin{array}{l}31-34 \text { Kda } \\
\text { PG fraction from } H 38(R)\end{array}$} \\
\hline A59/10F09/G10 & $\operatorname{IgG} 2 \mathrm{a}$ & $6 \cdot 25(0 \cdot 36)$ & $6 \cdot 27(0 \cdot 22)$ & 270 & $0 \cdot 857$ & 30 & $0 \cdot 619$ \\
\hline \multicolumn{8}{|l|}{$\begin{array}{l}\text { 36-38 Kda } \\
\text { PG fraction from H38 (R) }\end{array}$} \\
\hline $\begin{array}{l}\mathrm{A} 63 / 11 \mathrm{E} 05 / \mathrm{D} 11 \\
\mathrm{~A} 63 / 08 \mathrm{D} 08 / \mathrm{C} 07 \\
\mathrm{~A} 63 / 03 \mathrm{H} 02 / \mathrm{B} 01 \\
\mathrm{~A} 63 / 05 \mathrm{~A} 07 / \mathrm{A} 08 \\
\mathrm{~A} 63 / 04 \mathrm{D} 11 / \mathrm{G} 01 \\
\mathrm{~A} 63 / 13 \mathrm{G} 02 / \mathrm{C} 04\end{array}$ & $\begin{array}{l}\text { IgG1 } \\
\text { IgG1 } \\
\text { IgG1 } \\
\text { IgA } \\
\text { IgG2a } \\
\text { IgG1 }\end{array}$ & $\begin{array}{l}6.39(0.20) \\
6 \cdot 19(0.47) \\
6 \cdot 24(0.26) \\
6 \cdot 25(0.22) \\
5 \cdot 50(0.39) \S \\
6 \cdot 39(0 \cdot 16)\end{array}$ & $\begin{array}{l}5.84(0.43) \\
6.24(0.20) \\
6.29(0.27) \\
6.12(0.30) \\
5.93(0.43) \\
6.05(0.26)\end{array}$ & $\begin{array}{l}270 \\
810 \\
810 \\
810 \\
270 \\
810\end{array}$ & $\begin{array}{l}0.457 \\
0.735 \\
0.993 \\
0.570 \\
0.886 \\
1.294\end{array}$ & $\begin{array}{r}90 \\
270 \\
90 \\
270 \\
10 \\
270\end{array}$ & $\begin{array}{l}0.409 \\
0.592 \\
0.780 \\
0.476 \\
0.335 \\
0.826\end{array}$ \\
\hline \multicolumn{8}{|l|}{$\begin{array}{l}89 \mathrm{Kda} \\
\text { Cell wall from B115(R) }\end{array}$} \\
\hline $\begin{array}{l}\quad \text { A53/10B02/A01 } \\
\text { S-LPS (A) } \\
\text { S-LPS fraction, B. abortus B3 }\end{array}$ & IgG1 & $6 \cdot 20(0 \cdot 41)$ & $6 \cdot 45(0 \cdot 15)$ & 270 & $0 \cdot 590$ & 10 & $0 \cdot 314$ \\
\hline $\begin{array}{l}\text { B66/04F09 diluted } 1 \text { in } 200 \\
\text { Control: saline }\end{array}$ & $\operatorname{IgG} 2 \mathrm{a}$ & $\begin{array}{l}4.98(0 \cdot 14) \S \\
6 \cdot 30(0 \cdot 59)\end{array}$ & $\begin{array}{l}\cdots \\
\cdots\end{array}$ & 10 & $0 \cdot 117$ & 810 & $2 \cdot 001$ \\
\hline $\begin{array}{l}\text { Control: ascites no anti-brucella } \\
\text { activity }\end{array}$ & & & & 90 & 0.304 & 30 & $0 \cdot 422$ \\
\hline $\begin{array}{l}\text { MAbs were injected subcutane } \\
\text { from spleen were counted. } \\
\text { † Higher dilution that gave an } A_{4} \\
\ddagger \text { Maximal } \mathbf{A}_{414} \text { value after subtra } \\
\S \mathbf{p}<0.01 \text { in comparison with unt }\end{array}$ & $\begin{array}{l}\text { y } 1 \text { day } b \\
\text { alue great } \\
\text { n of blan } \\
\text { ed contro }\end{array}$ & $\begin{array}{l}\text { challenge with } \\
\text { n twice the bla } \\
\text { ps (one-sided I }\end{array}$ & $\begin{array}{l}200000 \mathrm{cfu} \text { of } \\
\mathrm{k} \text { value. } \\
\text { unnett's test). }\end{array}$ & n 544(S & ice were kill & & Ind Brucellae \\
\hline
\end{tabular}


(BioRad, Richmond, USA) $0.06 \% \mathrm{w} / \mathrm{v}$ and $5 \mathrm{mM} \mathrm{H}_{2} \mathrm{O}_{2}$ in TBS. The reaction was stopped by washing with distilled water.

\section{Results}

\section{Protection conferred on mice}

In experiment 1 (table I), MAb A19/12B10/F04 (anti-25-27 Kda OMP) and MAb A63/04D11/G01 (anti-36-38 Kda OMP) produced significant reductions of spleen counts at day 7 at the 1 in 5 dilution $\left(d^{\prime}=0.64, p<0.05 ; d^{\prime}=0.80, p<0.01\right)$. In experiment 2 (table II), MAb A19/12B10/F04 and MAb A18/ 13D02/F05 (anti-25-27 Kda OMP) (negative results in experiment 1) were tested again with 14 others. $\mathrm{MAb}$ A19/12B10/F04 was protective at both dilutions (5.21 p <0.01, 5.57 p <0.05; $d^{\prime}=0.62, \quad p<0.05$; $\mathrm{d}^{\prime}=0.78, \mathrm{p}<0.01$ ). MAb A66/05H01/E09 (anti$16.5 \mathrm{Kda}$ OMP) was protective at the 1 in 5 dilution $(5.54 \mathrm{p}<0.05)$ but MAb A18/13D02/F05 (anti-25-27 $\mathrm{Kda}$ OMP) gave most efficient protection at the 1 in 50 dilution $(5 \cdot 60, \mathrm{P}<0 \cdot 05)$. The negative and positive control results were as expected.

Overall, three MAbs out of 26 reduced spleen counts at day 7 in the mouse model. The three protective MAbs were obtained from mice immunised with living virulent Brucella (S) organisms, or with cell walls and PG fractions from $B$. melitensis strains 115 (R) and H38 (R). These MAbs belonged to isotypes IgG1 and IgG2a and reacted specifically with OMPs of $16 \cdot 5,25-27$, and $36-38 \mathrm{Kda}$.

Table II. Protective activity and binding of the anti-brucella OMP MAbs on R and S Brucella cells (experiment 2)

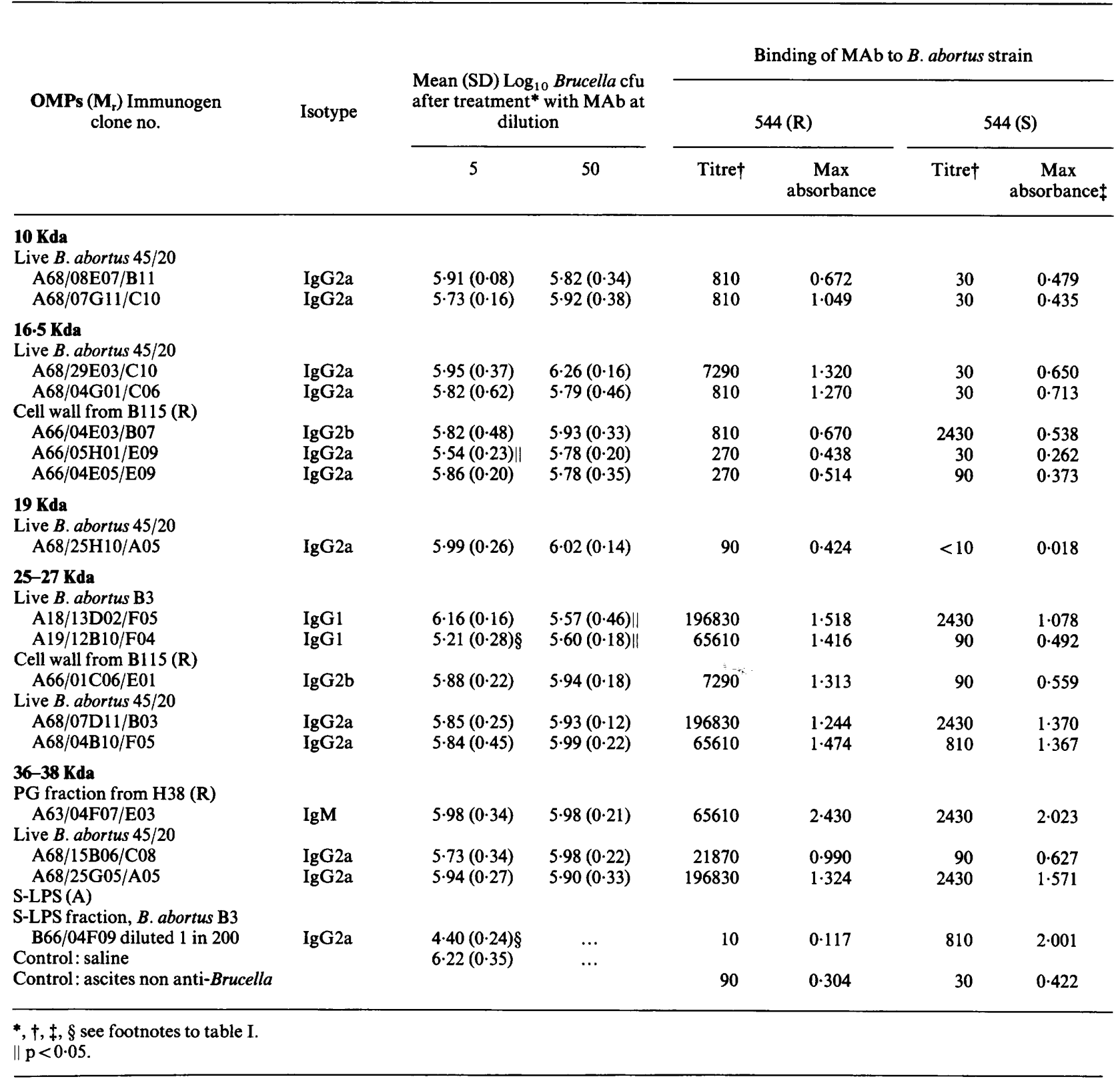




\section{Determination of $O M P$ specificity by Western} immunoblot analysis

The specificity of the protective anti-OMP MAbs was checked by Western immunoblotting with sonicated cell extracts of $B$. melitensis strain B115 (R) as antigen (figure). Multiple bands (doublets or triplets) were observed with the anti-25-27 and -36-38 Kda MAbs. A single band was observed for the anti-16.5 $\mathrm{Kda}$ protective MAb.

\section{Binding of MAbs to the brucella cell surface}

The ability of MAbs to bind to the cell surface of intact cells of $B$. abortus strain $544 \mathrm{R}$ and $\mathrm{S}$ variants was determined by ELISA (tables I and II). Most of the anti-OMP MAbs showed better binding to $B$. abortus strain $544 \mathrm{R}$ cells than to $\mathrm{S}$ cells. Most of the anti-10, -16.5 and $-19 \mathrm{Kda}$ MAbs bound only to $\mathbf{R}$ cells. The major OMPs of $25-27$ and 36-38 Kda were much less accessible on $S$ cells than on $R$ cells. No correlation was found between protective activity of the MAbs and their ability to bind to the cell surface. Some MAbs directed against the 25-27 Kda OMP bound more effectively to the cell surface than the

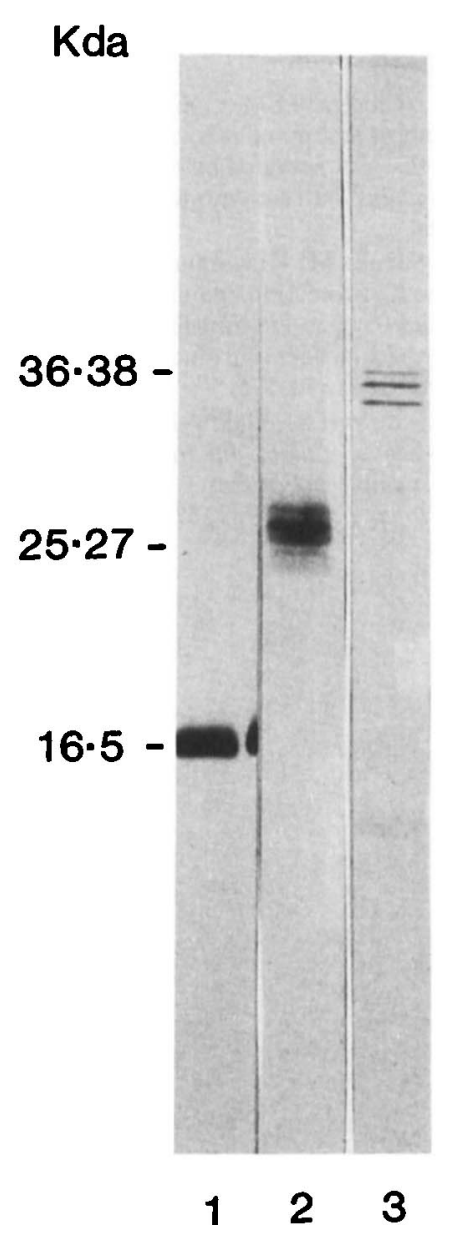

Figure. Immunoblot of sonicated heat-killed cell extracts of $B$. melitensis strain B115 (R) with (1) anti-16.5 Kda MAb A66/05H01/ E09, (2) anti-25-27 Kda MAb A19/12B10/F04 and (3) anti-36$38 \mathrm{Kda} \mathrm{MAb}$ A63/04D11/G01. anti-25-27 Kda protective MAb but were not able to protect mice from infection.

\section{Discussion}

Polyclonal immune sera raised against the PG fraction that reacted strongly with OMPs and S-LPS in immunoblots were highly protective in the mouse model. ${ }^{2,4}$ Having shown that MAbs directed against the LPS A or M dominant antigen conferred good protection, ${ }^{11,13}$ we produced 26 MAbs against $\mathrm{OMPs}^{16}$ which were screened in our mouse model for protection. Three were able to induce a significant reduction of spleen counts at day 7 after challenge. Using a similar approach, Montaraz et al. ${ }^{8}$ obtained protection with $\mathrm{O}$-polysaccharide (LPS)-specific MAbs but no protection with two anti-porin (37$38 \mathrm{Kda}$ ) IgM MAbs. The protection conferred by our three anti-OMP MAbs even if highly significant, was quite low compared with that conferred by the S-LPS positive control MAb (B66/04F09). The low protective effect induced by anti-OMP MAbs may be related to weaker opsonisation resulting from poor fixation at the cell surface, possibly because of low accessibility and avidity. One MAb showed a protective activity only at a dilution of 1 in 50 ; a detrimental effect following high-dose antibody administration in animals challenged with Staphylococcus aureus has been shown $^{23}$ which may be due to blockade of the immune system. There was no clear correlation between binding of anti-OMPs MAbs to the challenge $S$ strain and its $\mathrm{R}$ mutant and protection. This probably means that the binding of MAbs to cells in vitro is only a part of the protective action of MAbs in vivo. A complex mechanism of action of antibodies may operate during ingestion and killing of Brucella organisms by macrophages $^{14}$ and antibody-dependent cell-mediated cytotoxicity may also be involved. ${ }^{24}$

MAbs protective against other gram-negative bacteria have been described. ${ }^{25-28}$ However, most mouse models of protection are based on lethality and comparisons are difficult. Nevertheless, Sawada et al. showed that MAbs to OMPs were much less protective than MAbs to S-LPS against infection of mice with Pseudomonas aeruginosa. ${ }^{27}$

The role of anti-OMP antibodies in immunity to brucellosis remains uncertain. Using the MAbs we have developed, it should be possible to investigate the effects of these MAbs in vivo on the first phase of the infection, the possible synergy of two or more MAbs, and the mechanisms at the cellular level of digestion and killing of intracellular Brucella organisms.

We are grateful to J. M. Verger and M. Grayon for supplying strains. We thank V. Olivier-Bernardin, G. Bézard, A. Van Rompaye and J. Van Broeck for expert technical assistance. A. Cloeckaert was supported by the Institut National pour l'encouragement de la Recherche Scientifique dans l'Industrie et l'Agriculture (IRSIA). This work was supported by the Commission of the European Communities, contract BAP: 1986-1989. 


\section{References}

1. Pavlov H, Hogarth M, McKenzie IFC, Cheers C. In vivo and in vitro effects of monoclonal antibody to Ly antigens on immunity to infection. Cell Immunol 1982; 71 : 127-138.

2. Plommet $\mathbf{M}$. Brucellosis and immunity: humoral and cellular components in mice. Ann Inst Pasteur/Microbiol 1987; 138: $105-110$.

3. Dubray G. Protective antigens in brucellosis. Ann Inst Pasteur/ Microbiol 1987; 138: 84-86.

4. Plommet M, Serre A, Fensterbank R. Vaccines, vaccination in brucellosis. Ann Inst Pasteur/Microbiol 1987; 138: 117-121.

5. Madraso ED, Cheers C. Polyadenylic acid-polyuridylic acid (polyA:U) and experimental brucellosis. II. Macrophage as target cells of poly $\mathrm{A}: \mathrm{U}$ in experimental brucellosis. Immunology $1978 ; 35$ : 77-84

6. Bascoul S, Cannat A, Huguet M-F, Serre A. Studies on the immune protection to murine experimental brucellosis conferred by Brucella fractions. I. Positive role of immune serum. Immunology $1978 ; 35$ : 213-221.

7. Montaraz JA, Winter AJ. Comparison of living and nonliving vaccines for Brucella abortus in BALB/c mice. Infect Immun $1986 ; 53: 245-251$

8. Montaraz JA, Winter AJ, Hunter DM, Sowa BA, Wu AM Adams LG. Protection against Brucella abortus in mice with O-polysaccharide-specific monoclonal antibodies. Infect Immun 1986; 51 : 961-963.

9. Pardon P. Resistance against a subcutaneous Brucella challenge of mice immunized with living or dead Brucella or by transfer of immune serum. Ann Immunol (Inst Pasteur) 1977; 128C: 1025-1037.

10. Sulitzeanu DL. Passive protection experiments with Brucella anti-sera. J Hyg 1955; 53: 133-142.

11. Limet JN, Plommet A-M, Dubray G, Plommet M. Immunity conferred upon mice by anti-LPS monoclonal antibodies in murine brucellosis. Ann Inst Pasteur/Immunol 1987; 138 417-424.

12. Vendrell JP, Delobbe A, Huguet MF, Peraldi F, Serre A Cannat A. Biological properties of a panel of murine monoclonal anti-Brucella antibodies. Immunology 1987; 61: $7-10$.

13. Alton GG, Jones LM, Angus RD, Verger JM. Techniques for the brucellosis laboratory. Institut National de la $\mathbf{R e}-$ cherche Agronomique, Paris, France. 1988: 34-42, 113 122.

14. Limet JN, Bosseray N, Garin-Bastuji B, Dubray G, Plommet M. Humoral immunity in mice mediated by monoclonal antibodies directed against the two $A$ and $M$ antigens of Brucella. J Med Microbiol 1989 ; 30: 37-43.

15. Ralston DJ, Elberg SS. Serum-mediated immune cellular responses to Brucella melitensis Rev 1. II. Restriction of
Brucella by immune sera and macrophages. $J$ Reticuloendothel Soc 1969; 6: 109-139.

16. Dubray G, Charriault C. Evidence of three major polypeptide species and two major polysaccharide species in the Brucella outer membrane. Ann Rech Vét 1983; 14: 311318

17. Leong D, Diaz R, Milner K, Rudbach J, Wilson JB. Some structural and biological properties of Brucella endotoxin. Infect Immun 1970; 1: 174-182.

18. Limet JN, Berbinschi A, Cloeckaert A, Cambiaso CL, Masson PL. Longitudinal study of brucellosis in mice by immunoassay of lipopolysaccharide-related antigens in blood and urine. $J$ Med Microbiol $1988 ; 26: 37-45$.

19. Steel RGD, Torrie JH. Principles and procedures of statistics, with special reference to biological sciences. New York, McGraw-Hill Book Company, Inc. 1960: 111-112.

20. Nakane PK, Kawaoï A. Peroxidase-labelled antibody, a new method of conjugation. J Histochem Cytochem 1974; 22 . 1084-1091.

21. Dubray G, Limet J. Evidence of heterogeneity of lipopolysaccharides among Brucella biovars in relation to $\mathbf{A}$ and $\mathbf{M}$ specificities. Ann Inst Pasteur/Microbiol 1987; 138: 27-37.

22. Laemmli UK. Cleavage of structural proteins during the assembly of the head of bacteriophage T4. Nature 1970; 227: 680-685.

23. Greenberg DP, Bayer AS, Cheung AL, Ward JI. Protective efficacy of protein A-specific antibody against bacteremic infection due to Staphylococcus aureus in an infant rat model. Infect Immun 1989; 57: 1113-1118.

24. Galdiero F, Romano Carratelli C, Nuzzo I, Folgore A. Cytotoxic antibody dependent cells in mice experimentally infected with Brucella abortus. Microbiologica 1985; 8: 217-224.

25. Brodeur BR, Larose Y, Tsang P, Hamel J, Ashton F, Ryan A Protection against infection with Neisseria meningitidis group $B$ serotype $2 \mathrm{~b}$ by passive immunization with serotype-specific monoclonal antibody. Infect Immun 1985 50: $510-516$

26. Hansen EJ, Robertson SM, Gulig PA, Frisch CF, Haanes EJ. Immunoprotection of rats against Haemophilus influenzae type $\mathrm{b}$ disease mediated by monoclonal antibody against $\mathrm{a}$ Haemophilus outer-membrane protein. Lancet 1982; 1: 366-368.

27. Sawada S, Suzuki M, Kawamura T, Fujinaga S, Masuho $Y$, Tomibe K. Protection against infection with Pseudomonas aeruginosa by passive transfer of monoclonal antibodies to lipopolysaccharides and outer membrane proteins. J Infect Dis 1984 ; 150: 570-576.

28. Zhang Y-X, Stewart SJ, Caldwell HD. Protective monoclonal antibodies to Chlamydia trachomatis serovar- and serogroup-specific major outer membrane protein determinants. Infect Immun 1989; 57: 636-638. 